\title{
A Comparative Study of Language Instructional Delivery System between Nursery Schools in Rural and Urban Areas in Osun State
}

\author{
Odejobi, Cecilia Omobola ${ }^{1, *}$ \\ ${ }^{1}$ Institute of Education, Faculty of Education, Obafemi Awolowo University, Ile-Ife, Nigeria \\ *Correspondence: Institute of Education, Faculty of Education, Obafemi Awolowo University, Ile-Ife, Nigeria. Tel: \\ 234-803-715-2526. E-mail: bolaodejobi1@gmail.com
}

Received: June 27, 2014

Accepted: August 21, $2014 \quad$ Online Published: September 5, 2014

doi:10.5430/wje.v4n5p31

URL: http://dx.doi.org/10.5430/wje.v4n5p31

\begin{abstract}
The study compared the language instructional delivery system between the nursery schools in rural and urban areas in Osun state. The population consisted of all the nursery school teachers in Osun state. Proportionate random sampling was used to prune down the population. In all 130 nursery school teachers, 68 in urban areas and 62 in rural areas served as respondents of the study selected from 30 nursery schools located in rural and urban areas. A researcher made instrument named Teachers' Questionnaire (TQ) was designed for data collection. The questionnaire was validated before use and the reliability coefficient yielded 0.85 which is significant at 0.05 level of significance. Data were analysed statistically using t-test analysis and percentages. Findings showed that there was no significant difference between the methods adopted for implementing language curriculum in nursery schools located in both rural and urban areas. A significant difference existed between the human resources available in nursery schools located in both rural and urban areas. It was also found out that there was no curriculum for Yorùbá language in most of the nursery schools visited. The study concluded with recommendations for both proprietors of nursery schools in rural and urban areas to improve on their present standard in terms of teaching personnel, instructional resources and teaching/learning process, nursery school teachers and the three-tiers of government.
\end{abstract}

Keywords: instructional delivery system; language curriculum; rural and urban areas; early childhood education

\section{Introduction}

The life of any child between 0-5 years is very crucial for developing the right types of concepts, attitude and setting to socialize the child. Hence, parents are the first educators of child because they are the core setting for socializing the child while the teachers build on whatever foundation laid at home (Goodson, 2000). The entire early development is a result of his/her experiences within the family context, though subject to change as the child interacts more and more with people outside the family. Thus, children are taught to act, believe and feel in ways that are consistent with the mores of their communities (Bowman, 1989). A child is not a mere bundle of psychological factors but a psychosocial being whose inner mystery makes him/her a complete personality. This affords a child the opportunity to deserve an in-depth educational consideration. Hence he/she comes to School with a lively mind, an inborn disposition to make sense of the experiences, observations and feelings already gained from home.

Since early childhood education takes after the home, instructional strategies should be informal and consist largely of child-initiated activities. By this, young children will become active constructors of knowledge. Katz (1996) opined that child-initiated curricular may utilize learning centers within classroom, promote learning from play-based activities, or encourage child interaction and cooperation. As a result, academic learning, which will occur in child-initiated learning environment, may not result from teacher-led formal didactic (seat, work, lectures, etc) instruction, but from a variety of child-initiated learning activities (Katz, 1999).

The objective of pre-primary education is to effect a smooth transition from home to the primary school. Therefore, the starting point for all the subject in the curriculum is what the child knows in order to establish what can be taught next (Bruce, 1989). Hence, the use of language plays an important role in the social and emotional development of children. Any child who cannot talk to others misses companionship and the opportunity to make those close ties, which pave the way for normal development. According to Halliday (1998) and Brunner (1983) in communicating 
with other people, language carries with it an unspoken network of culture values. These values operate on a subliminal and they are a major force in the shaping of each person's self awareness, identity and interpersonal relationship (Scollon\&Scollon, 1981).

\subsection{Early Childhood Education}

Early childhood Education is about challenging children and encouraging them to develop into motivated learners and thinkers, full of curiosity about the world around them. Developmental psychologists like Piaget, Frobel, Montessori, Mc Milan and Isaacs shared the opinion that the young child is a whole person with thoughts, imagination and feelings to be cared for and cherished. They believed that children are intrinsically motivated and wish to learn (Curtis, 1986).

Various scholars and bodies like UNICEF (1992), Abdullahi (1997), FRN (2004) and Akinyode (2005) have attempted to define the term early childhood education. Based on the consensus of opinion, pre-primary education otherwise called early childhood or nursery education is the education given in an educational institution to children aged three to five years plus, prior to their entering the primary school. Therefore, every child deserves a good start in life. The early years are the time when a child develops physically, emotionally and intellectually at a fast pace and this is the foundation for a healthy, secure and alert person.

According to Oduolowu (2003) the Federal Government of Nigeria (FGN) has realized that just as the foundation of a building starts with excavating, leveling and scaling so also is the early childhood education essential for realistic primary education. The FRN (2004) has articulated a comprehensive policy for this level as part of the National Policy on Education (NPE) to cover the period of zero to five years of age. The objectives stated below aimed at the holistic development of the child:

a. Affecting a smooth transition from the home to the school;

b. Preparing the child for the primary level of education;

c. Providing adequate care and supervision for the children while their parents are at work (on the farms, in the market, offices etc);

d. Inculcating social norms;

e. Inculcating in the child the spirit of enquiring and creativity through the exploration of nature, and the local environment, playing with toys, artistic and musical activities, etc;

f. Teaching cooperation and team spirit;

g. Teaching rudiments of numbers, letters, colours, shapes, forms etc., through play; and

h. Teaching good habits, especially good health habits.

With these, early childhood education is a preparation for life and not just giving children a systematic knowledge set out in a syllabus. Early childhood education is not just about school but making the most of the ability which every child has to learn and absorb new aspects of life and adopt new patterns of behavior.

\subsection{Language and Language Curriculum}

Language is a distinctive quality of mind that is unique to man. According to Fox (1990) language is a human affair, diverse, sprawling and open ended. It depends for its effectiveness entirely on sets of rules or conventions, which govern the way in which meanings are assigned, either to sound or to written symbols. Because of the rules that guide the combination of sounds into words and words into acceptable sentences, it is of paramount importance that young children start on a right footing.

Language as a symbolization of thought (Bowen, 1998). It is a learned code, a system of rules that enables us to communicate ideas and express wants and needs. The child learns language because it is useful in communicating his/her feelings, wishes and desires. Language acquisition of all children occurs gradually through interaction with people and the environment. Language is not only a means of communication; it is also a tool for thinking (Curtis, 1986).

Language is a veritable vehicle of interaction and a means of education through which human beings pass their culture from one generation to another. It is important therefore that children's experience with communication and literacy begins to form the basis for their later school success. The development of language is dependent upon the amount of practice children have in both speaking and listening. Children bring to school diverse level of language acquisition to the learning process (Aldridge, 2005). It becomes the teachers business to face the challenge of 
meeting the individual needs of each language learners, as well as discerning which methods work most effectively in enhancing language development.

Kats (1999) asserted that an appropriate curriculum address strengthening and using the intellectual dispositions, offers good process about rich content and results in high quality product. Early childhood curriculum should focus on (a) social/emotional development; (b) intellectual development; and (c) the acquisition of meaningful and useful academic skills. To achieve all these, Corson, (1998) asserted that the curriculum for the first experience should be oral language. This is because nothing is more important to their education in these years than their oral language development. For this reason, the language curriculum is basically on the natural order of listening and speaking for effective communication, with reading and writing aspects gradually following as they progress towards primary education.

\subsection{Instructional Delivery System}

A longstanding curriculum debate in early childhood education centers on whether it should follow the traditional academic model of education used with older students or whether learning experiences for pre-primary children should be informal and consist of child initiated activities. Among these works are: Schweinhart\&Weikart, (1997a); Schweinhart\&Weikart, (1997b); and Cotton \& Conklin, (2001). These researchers support the use of curriculum approach based on child-initiated learning activities rather than teacher directed lessons. Hence, language development in child-initiated and developmentally appropriate programmes was associated with better language outcomes (Banks, 2001).

Developmental programmes are designed to meet all the needs of young children and provide programming that is personally meaningful to each and every child within the context of the child's culture, primary language and family (Nissani, 1993). Therefore, the type of language instructional delivery system to be used should be the one that will support the vast numbers of experiences children need before they can arrive at an awareness of themselves and the world. The teachers are therefore required to find possible modes of teaching which is appropriate for the child in order to equip him with the necessary tools for future career and development.

Several teaching methods and approaches have been prescribed by various schools ranging from situational language teaching (SLT) and Audio-Lingualism (AL). These methods were succeeded by silent way, Suggestopedia, Community Language Learning and total Physical Response. These methods were also overshadowed by more interactive views of language teaching - the Communicative Language Teaching (CLT) (Rogers, 2001). To get a sense of the range of these methods, their synoptic or summary are presented in table 1 below:

Table 1. Teaching Methods and Teachers \& Learners Roles

\begin{tabular}{lll}
\hline TEACHING METHODS & TEACHER ROLES & LEARNER ROLES \\
\hline Situational Language Teaching & Context Shelter & Imitator \\
& Error Corrector & Memorizer. \\
Audio-Lingualism & Language Modeler & Pattern Practicer \\
& Drill Leader & Accuracy Enthusiast \\
Communicative Language Teaching & Needs Analyst & Improvisor \\
& Task Designer & Negotiator \\
Total Physical response & Commander & Order Taker \\
& Actor Monitor & Performer \\
Community Language Learning & Counselor & Collaborator \\
\multirow{2}{*}{ The Natural Approach } & Paraphraser & Whole Person \\
& Actor & Guesser \\
Suggestopedia & Props User & Immerser \\
& Auto-hypnotist & Relaxer \\
& Authority figure & true-Believer \\
\hline
\end{tabular}

Source: Rogers (2001).

From the above table, Situational Language Teaching, Audio-Lingualism, The Natural Approach, Suggestopedia and Total Physical Response see the teacher as ideal language model and commander of classroom activities. Communicative Language Teaching and Community Language Learning see the teacher as background facilitator and classroom colleague to the learners. Language is a predicator in the literacy development of children; the teacher therefore needs to employ the methods that will allow the child to use language. In order to manage children activities very well and stimulate conversation, the concept of play with the use of instructional materials should be 
employed because it contributes to young child's cognitive, social and psychological developments

\subsection{Rural and Urban Language}

Schools in rural areas according to Cartwright and Allen (2002) are schools in town areas, that is, those schools located outside big cities while schools in urban areas are those located in census metropolitan areas and thus located in big cities that have a high degree of economic and social integration. Schools in urban areas are generally better maintained and equipped than those in rural areas because schools in urban areas received more funding than their rural counterpart. This afford schools in urban areas the opportunities for early learning which are unequally distributed due to availability of more institutions in urban areas than in rural areas (UNESCO, 2005).

Schools in urban areas recruit more highly qualified teachers and provide greater curricular varieties and educational resources. It is based on these issues that this study compared the Language Instructional delivery system between rural and urban nursery schools in Osun State. These have implication for mode of instructional delivery in schools. The situation is made worse in view of the fact that ministry's supervision of rural schools is very minimal. Also informal observation reveals that bulks of the teachers in rural nursery schools are untrained and uncertificated. It thus becomes imperative to examine the effect of these factors among nursery schools. Previous research efforts have been concentrated on primary and secondary schools while research results on nursery education is lacking. The study more specifically will compare the instructional delivery method in Yorùbá language among rural and urban nursery schools. The reason why Yorùbá language becomes the subject of investigation is because the National Policy of Education (FRN, 2004) specified that indigenous language be used for instruction in early childhood education. Results from this study are expected to guide in better direction of effort toward implementation of early childhood curriculum.

\subsection{Objectives of the Study}

The objectives of the study were to:

1) compare the mode of instruction delivery in nursery schools situated in both rural and urban areas.

2) compare teachers' qualification and competency in nursery schools located in rural and urban areas.

3) examine the adequacy of instructional materials for the implementation of language curriculum in nursery schools located in rural and urban areas.

\subsection{Research Questions}

1) Is there a curriculum for Yorùbá language in both schools situated in rural and urban areas?

2) Is the mode of instruction delivery in nursery schools located in rural areas different from that of nursery schools located in urban areas?

3) Are the teachers in nursery schools located in urban areas more qualified and competent than those in the nursery schools located in rural areas?

4) Are there adequate resources for the implementation of language curriculum in nursery schools located in urban area than in nursery schools located in rural areas?

\section{Methodology}

The study adopted ex-post-facto research design. The population for the study is made up of all nursery school teachers in Osun state. The proportionate random sampling technique was used to prune down the population to four local Government Areas in Ife, and to determine the number of schools to be used as well as the number of subjects' total population for the study. In all, 30 nursery schools were selected having 15 schools each in urban and rural areas. The total numbers of respondent were 130 nursery school teachers: 68 in urban areas and 62 in rural areas.

A researcher's made instrument named. Teachers' Questionnaire (TQ) was designed for data collection. The questionnaire was divided into sections A and B, section A deals with the personal data of the teachers. Section B contains 18-item structured questions to collect information on language instructional delivery system. The data collected was analyzed using t-test analysis and percentages. 


\section{Result}

Research Question 1: Is there a curriculum for Yorùbá language in nursery schools situated in both urban and rural areas?

Table 2. Teachers Response on Yoruba Curriculum

\begin{tabular}{|c|c|c|c|c|c|c|c|c|c|c|c|}
\hline $\mathrm{S} / \mathrm{N}$ & Items & Urban & Yes & $\%$ & No & $\%$ & Rural & Yes & $\%$ & No & $\%$ \\
\hline 1. & $\begin{array}{l}\text { Do you have Yorùbá as a } \\
\text { subject? }\end{array}$ & 68 & 30 & 44 & 38 & 56 & 62 & 40 & 65 & 22 & 35 \\
\hline 2. & Do you have curriculum for & & & & & & & & & & \\
\hline & Yorùbá like other subjects? & & 10 & 14 & 58 & 86 & & 14 & 23 & 48 & 77 \\
\hline 3. & $\begin{array}{l}\text { Are there standard textbooks for } \\
\text { teaching Yorùbá in nursery } \\
\text { school? }\end{array}$ & & 5 & 7 & 63 & 93 & & 8 & 13 & 54 & 87 \\
\hline 4. & $\begin{array}{l}\text { Do you lift what to be taught } \\
\text { from English Language } \\
\text { curriculum? }\end{array}$ & & 85 & 86 & 10 & 14 & & 48 & 77 & 14 & 23 \\
\hline 5. & $\begin{array}{l}\text { Non-availability of Yorùbá } \\
\text { language curriculum is not } \\
\text { promoting the teaching and } \\
\text { learning of the subject. }\end{array}$ & & 60 & 88 & 8 & 12 & & 60 & 96 & 2 & 4 \\
\hline
\end{tabular}

Table 5 above addresses question 4 and shows teachers' response on availability of Yorùbá curriculum. 44\% and 65\% of the respondents from schools in urban and rural areas respectively confirmed availability of Yorùbá as a subject while 56\% and 35\% from both areas said otherwise. Minority of the respondents, $14 \%$ and $23 \%$ from urban and rural areas respectively agreed that there is curriculum for Yorùbá like other subject while majority of them $86 \%$ and $77 \%$ confirmed the non-availability of Yorùbá curriculum. $7 \%$ and 13\%of the respondents from schools in urban and rural areas respectively agreed that there are standard textbooks for teaching Yorùbá in nursery school while 93\% and 87\% responded negatively. Majority of the respondents $86 \%$ and $77 \%$ from schools in urban and rural areas lift what to be taught from English Language curriculum while minority of them $14 \%$ and $23 \%$ responded negatively. A large percentage of the respondents $88 \%$ and $96 \%$ responded positively that non-availability of Yorùbá language curriculum is not promoting the teaching and learning of the subject while a small percentage of the respondents $12 \%$ and $4 \%$ responded otherwise. From the above analysis, it was clear that Yorùbá language curriculum was not available for the teaching and learning of the subject in Urban and rural nursery schools

Research Question 2: Is the mode of instruction delivery in nursery schools located in rural areas different from that of nursery schools located in urban areas?

Table 3. T-Test Analysis for Implementing Language Curriculum in Nursery Schools Located in both Urban and Rural Areas

\begin{tabular}{lcccccc}
\hline Group & $\mathrm{N}$ & - & $\mathrm{Sd}$ & $\mathrm{Df}$ & $\mathrm{Tc}$ & $\mathrm{Tt}$ \\
\hline Urban & 8 & 39.75 & 17.04 & 7 & 1.20 & 2.365 \\
Rural & 8 & 30.5 & 13.46 & & & \\
\hline
\end{tabular}

In table 3 , the mean score of nursery institutions located in urban area is 39.75 while that of rural area is 30.5 . When these mean scores were compared, the $t_{c}$ value is 1.20 and the $t_{t}$ was 2.365 . The value is found not to be significant at the 0.05 level of significance. This showed that the method adapted for implementing Yorùbá language curriculum in nursery schools located in urban and rural areas are the same.

Research Question 3:Are the teachers in nursery institutions located in urban area more qualified and competent than those in the nursery schools located in rural area?

Table 4. T-Test Analysis of Available Human Resources in Nursery Schools Located in both Urban and Rural Areas

\begin{tabular}{lcccccc}
\hline Group & $\mathrm{N}$ & - & $\mathrm{X}$ & $\mathrm{Df}$ & tc & $\mathrm{Tt}$ \\
\hline Urban & 8 & 32.5 & 15.17 & 7 & 2.8 & 2.365 \\
Rural & 8 & 16.125 & 6.58 & & & \\
\hline
\end{tabular}


The Result as summarized in table 3 shows that the mean scores of nursery schools located in urban area is 32.5 while that of nursery schools located in rural area is 16.125 . When the mean values were compared, the resultant $t_{c}$ is 2.8 and $t_{t}$ is 2.365 . This shows that the values are significant at 0.05 level of significance. This showed that there is a difference between the available human resources in nursery schools located in both urban and rural areas.

Research Question 4: Are there adequate resources for the implementation of language curriculum in nursery schools located in urban area than in nursery schools located in rural areas?

Table 5. T-Test Analysis of Learning Resources of Nursery Schools Located in both Urban and Rural Areas

\begin{tabular}{lcccccc}
\hline Group & $\mathrm{N}$ & - & $\mathrm{Xd}$ & $\mathrm{Df}$ & $\mathrm{Tc}$ & $\mathrm{Tt}$ \\
\hline Urban & 8 & 43 & 16.22 & & 3.02 & 2.365 \\
Rural & 8 & 22.875 & 9.568 & 7 & &
\end{tabular}

The summary in table 4 shows that the mean score of learning resources of nursery schools located in urban area is 43 while that of nursery schools in rural area is 22.875 . When these values were compared, the resultant $t_{c}$ is 3.02 and $t_{t}$ is 2.365. This shows that the values are significant at the 0.05 level of significance. This showed that there is a significance difference between the available learning resources of nursery schools in both urban and rural areas

\section{Discussion}

The study reveals that there was no Yorùbá language curriculum in most of the schools visited. This could be the reason why a large number of the schools do not have Yorùbá language as a teaching subject on the time table. Schools where Yorùbá is being taught were left to face the peril of haphazard curriculum in Yorùbá language. According to Odejobi (2003), to achieve the objective of a good curriculum, it should not be a haphazard accumulation of desirable knowledge. There should be a well-planned curriculum in a school to guide and direct teachers in daily teaching-learning activities particularly in the nursery schools which is to prepare the child for subsequent learning activities and future life encounters. Therefore, this is a challenge to the government, Yorùbá Studies Association of Nigeria and EgbeAkomolédèYorùbá to find means of including Yorùbá language into the curriculum of nursery schools if we do not want an extinction of our culture in this society.

It was observed from the result of the study that there was no significant difference between the methods adopted for implementing language curriculum in nursery schools located in both urban and rural areas. This implies that the way or the method adopted in teaching Yoruba language in the nursery schools in urban area is not different from what is happening in nursery schools in rural area. The method used contradicts what the government stipulates in FRN (2004) that the main method of teaching in the pre-primary school will be through play. Going by what is happening in the nursery schools in both urban and rural areas, Yoruba language periods were used as memorization session. This binding confirmed the submission of Darling (1994) and Akinyode (2005) that emphasis is laid a rote learning in nursery schools, the hapless young stares are made to recite stereo-typed lines day-in-day-out without any regard for correct pronunciation and grammaticality.

The result also revealed that there was a significant difference between the available human resources in nursery schools in urban and rural areas. This implies that the nursery school teachers in urban area are more competent and qualified than their counterpart in rural area. In terms of qualification, the result showed that only $49 \%$ of the nursery school teachers in urban and $24 \%$ in rural areas sampled was qualified professionally to teach in accordance with the NPE guidelines. There are $21 \%$ and $39 \%$ semi-qualified nursery school teachers in urban and rural areas respectively while the rest 31\% and 37\% teachers in nursery schools in urban and rural areas respectively were auxiliaries. In terms of output, the result finding in table 3 lend credence to the fact that teachers in nursery schools situated in urban area were more competent than their counterpart in rural area. From these findings, nursery school teachers located in the urban areas are more qualified and competent than their colleagues in rural areas. There are also shortages of qualified teachers in nursery schools located in both urban and rural areas. These findings further confirmed the view of Emenanjo (1998), and Odejobi (1997) that there is a dearth of trained and qualified teachers all through Nigerian system of education. Qualifications are important in determining the qualities of nursery education hence distinction should be made between training and qualifications (ERO, 1996). This becomes unnecessary because not all training undertaken by nursery workers lead to a recognized nursery education qualification. Therefore, there should be in-service training for the qualified teachers to improve their skills and also, the unqualified teachers need to have access to high quality training that lead to a recognized qualification. 
The result also indicated that there is a significant difference between the available learning resources in nursery schools situated in both urban and rural areas. These differences resulted from the inadequacies of equipment and teaching learning material which featured prominently in nursery schools in rural areas. Also, according to Olaitan, Oniyangi, Oyerinde, and Onifade, (2012); Okobia(2012),instructional materials are not adequately available and so teacher does not use them.Table 6 summarizes the situation of learning resources in both nursery schools in urban and rural areas.

Table 6. Availability of Learning Resources in Nursery Schools in both Urban and Rural Areas

\begin{tabular}{lll}
\hline Learning Resources & $\begin{array}{l}\text { Percentage Availability } \\
\text { Urban }\end{array}$ & $\begin{array}{l}\text { Percentage Availability } \\
\text { rural }\end{array}$ \\
\hline Standard playground & 17.65 & 3.2 \\
Ladder & 48.53 & 24.2 \\
Swing & 23.5 & 0 \\
Sand trays & 48.53 & 27.4 \\
Realia & 17.7 & 9.7 \\
Textbooks & 58.2 & 21.7 \\
See saws & 23.5 & 9.6 \\
Hoops & 40.6 & 21.7 \\
Bean bags & 50.5 & 27.4 \\
Skipping rope & 38.6 & 24.2 \\
Dolls & 20.5 & 9.7 \\
Musical instrument & 2.9 & 0 \\
Radio & 45.5 & 24.2 \\
Merry-go-round & 17.7 & 9.7 \\
Television & 2.9 & 0 \\
Computer & 1.5 & 0 \\
Video equipment & 0 & 0 \\
Charts/Posters & 58.2 & 38.7 \\
Abacus & 23.5 & 9.7 \\
\hline
\end{tabular}

Source: Survey 2005.

According to Oduolowu (2003), equipment and teaching-learning materials play an important role in the life of young children. Proper utilization of instructional materials enhances learning and ensures adequate participation on the part of the students (Doublegist, 2013). Hence their inadequacies in the schools are very disturbing to effective and efficient teaching-learning process. Therefore effort should be made to embark on local production of teaching and learning resources and made available to proprietors at affordable prices.

\section{Conclusion}

Language is an important instrument of education, which should be taught appropriately at any level of our educational system and most especially at the early childhood level. This is necessary because early childhood level is the foundation of educational structure hence a solid dependable foundation on language is essential. No one can run away from language because no matter what the subject is students receive and assimilate new concept largely through language either in mother tongue or in the second language. Therefore, teachers must reflect on the effectiveness of delivery system used. This is a vital step in helping you become the best teacher you can be. Tempo of instruction must be kept to meet the needs and pace of students. This can be accomplished through flexible grouping, rotating through learning centers or using various web tools. Most importantly, be very enthusiastic about your instruction. Read stories with voices, allow yourself to be silly, and always add humor (Dabbs, 2012).

\section{Recommendation}

Based on the findings of this study, the following recommendations were made:

- The proprietors and proprietresses should encourage and insist on language development by making sure that the teachers engage in accountable talk, communicating through open-ended questions, building language and literacy through play and extending children's conversation and play scenarios. 
- They should not be pre-occupied on how to maximize profit only at the expense of rendering service to the nation but employ competent and qualified teachers who will be able to interpret any policy and even create one if need be.

- The teachers in nursery schools located in both urban and rural areas should try as much as possible to improve themselves by enrolling for in-service or part time programmes on their field so as to become masters in their training chosen career.

- They should interact with their urban counterparts to get hints of the new developments in teaching methods and learning resources.

- The three-tiers of government, that is, the federal, the state and the local, should step-in to give financial aids to nursery schools in both urban and rural areas.

- They should look beyond setting standard for the nursery schools but establish public ones to serve as models for the existing private ones,

- They should constitute a group of formidable inspecting institution that will really go to the field to ensure smooth running of the teaching/learning process.

- They should provide the opportunity for training and re-training of nursery school teachers to up-date them in content, methods and other aspect of language teaching.

\section{References}

Abdullahi, O.E. (2003). Fountains for life-long learning in early childhoodthrough UBE. In Ehindero, O.J, \& Aladejana, F.O. (eds.), Readings in early childhood and universal basic education. Ghana: Lantern Books

Akinyode, S. (2005). Beyond 6-3-3-4: A recipe for the education system in Nigeria. Nigeria matters.

Aldridge, J. (2005). Importance of oral language, The childhood education, The look smart knowledge for parents. Retrieved from http://www.looksmartparents.com/p/articles/miqa3614/is200504/ain13498775?pi=psf

Banks, R. (2001). The early childhood education curriculum debate: direct instruction vs. child-initiated learning, clearing house on early childhood education and parenting. Retrieved from http://ceep.ere.uiuc.edu/index.html

Bowen, C. (1998). Speech and language development.In Infant and young children. Retrieved from http:membertripod.Com/Caroline-bowen,development.htm

Bowman, B. T. (1989). Educating language minority children: challenges and opportunities. Phi. Delta Kappan, 71(2), 118-221.

Bruce, T. (1987). Early childhood education. London: Hodder \& Stoughton.

Brunner, J.S. (1983). Child talk. Oxford University press.

Cartwright \& Allen (2002). Understanding the rural-urban reading group. Ontario: Ministry of Industry

Corson, D. (1988). Oral language across the curriculum. Clevedon: Multilingual matters ltd.

Cotton, K., \& Conklin, N.F. (2001). Research on early childhood education.School improvement research series (SIRS), tropical synthesis \#3. Retrieved from http://www.nwrel.org/scpd/sirs/3/topsyn.3.html

Curtis, A.M. (1986). A curriculum for the pre-school child learning to learn. Windsor: Nfer-Nelson.

Dabbs, L. (2012). New teacher academy: Delivery of instruction. Retrieved from http://www.edutopia.org/blog/new-teacher-delivery-instruction-lisa-dabbs

Darling, J. (1994). Child-centered education and its critics. London: Paul Chapman.

Doublegist (2013). Instructional materials in teaching English language-effectiveness.DoubleGist.com. Retrieved from http://www.doublegist.com/instructional-materials-effectiveness-teaching-english-language/

Emenanjo, E.A. (1998). Language and the national policy on education: implications and prospects in Fafunwa foundation internet jounal of education. Nigeria.

ERO (1996). What counts as quality in childcare. Publication no. 1. Retrieved from http://www.ero.govt.ez/Publications/eers1996/96n01hl.htm

Federal Republic of Nigeria (2004). The national policy on education. Lagos: NERDC press 
Fox, R. (1990). English in the national curriculum, In Coulby, D. \& Ward, S., The primary core national curriculum: policy into practice. London: Cassell educational limited

Halliday, M. (1978). Language and social semiotic. London: Edward Arnold.

Katz, L.G. (1999). Curriculum disputes in early childhood education. Eric digest campaign, Il: ERIC clearing house on elementary\& early childhood. (ERIC document no. ED 436298).

Katz, L.G. (1996). Balancing constructivism in early childhood curriculum. Paper presented at the annual Maya Zuck lecture in early childhood education series. Washington University. St Louis, MO.

Nissani, H. (1993). Early childhood programs for language minority students. Cal digest on special populations. Washington DC: National clearing house for bilingual education (NCBE).

Odejobi, C. O. (2003). The state of Yorùbá curriculum in Nigerian primary schools: a proposal for a standard curriculum. Ife journal of theory and research, 8(1), 91-102.

Odejobi, C.O. (1997). Problems of Yorùbá language learning in Ife central local government schools. Ife journal of educational studies, 4(1), 85-90.

Oduolowu, E. A. (2003). Current status of early childhood education in Nigeria. In Ehindero, O.J, \&Aladejana, F.O. (eds.), Readings in early childhood and universal basic education. Ghana: Lantern Books.

Okobia E.O. (2012). Availability and teachers' use of instructional materials and resourcesin the implementation of social studies in junior secondary schools in Edo state, Nigeria. Review of European Studies, 3(2), 90-97. Retrieved from http://www.uniben.edu/abstracts/availability-and-teachers-use-instructional-materials-and-resources-implement ation-social-

Olaitan, O.L., Oniyangi, S.O., Oyerinde, O.O., \& Onifade, O.A. (2012). Availability and utilization of instructional materials for teaching health education in primary schools in Kwara State, Nigeria. E-International Scientific Research Journal, 4(2), 89.

Rogers, T.S. (2001). Language teaching methodology.Cal digest. Washington DC. ERIC clearing house on language and linguistics.eric@cal.org

Schweinhart, L.J., \& Weikart, D.P. (1997a). The high/scope pre-school curriculum comparison study through age 23. Early childhood research quarterly, 12(2), 117-143. ERIC journal no. EJ554350.

Schweinhart, L.J., \& Weikart, D.P. (1997b). Lasting differences: The high/scope pre-school curriculum comparison study through age 23. High/scope educational research foundation monograph no. 12 Ypsilanti. MI: High scope press, ERIC document no ED410019

Scollon, R., \& Scollon, S.B.K. (1981). Narrative, literacy and face in interethnic communication. Norward: NS Ablex.

UNESCO (2005). 60 year of education: Education for all. $5^{\text {th }}$ September 2005-4November 2006.

UNICEF (1992). Early childhood care and pre-primary (nursery education). National report on situation and policy analysis of basic education in Nigeria, 22-25, 53-63. 